\title{
Facilitating Linguistic Integration of Immigrants: An Overview of ICT Tools
}

\author{
Simon Collin \\ University of Quebec in \\ Montreal, Montreal, Quebec, \\ Canada
}

collin.simon@uqam.ca

\author{
Thierry Karsenti \\ University of Montreal, \\ Montreal, Quebec, \\ Canada
}

\begin{abstract}
This study looks at the current state of linguistic integration in Western societies (North America and Europe) at a time when international immigration is steadily growing and diversifying. Integration and its diverse components have therefore become a central aspect that must be supported and facilitated in contemporary societies. The potential contribution of information and communications technologies (ICT) to the linguistic integration of immigrants is explored, inspired by both the relevance of ICT for immigrants and the recent development of various online linguistic integration tools. The objective is to provide an international overview, albeit partial, of the role of ICT in the linguistic integration of immigrants at the social level, including descriptions and comparisons of ICT tools for linguistic integration. To do so, we conducted a review of the international literature on various mechanisms of linguistic integration as well as scientific studies on the topic. We present the main trends found. It appears that current linguistic integration mechanisms vary widely in terms of both technology and pedagogy, with abundant potential for facilitating immigrant integration. However, some limitations for language learning and social integration into the host society are noted.
\end{abstract}

Keywords: immigrants, ICT, linguistic integration, review of the literature, Western societies

\section{Introduction}

Linguistic integration has long been recognized as an important factor in the overall immigration process (Beacco, 2008; Kluzer, Ferrari \& Centeno, 2009). Briefly, linguistic integration has been accomplished when immigrants have the capacity to use one of the languages that is current in the host society for public communication (Lapierre Vincent, 2004), as opposed to personal communication (e.g., at home). This does not imply mastery of the language, comparable to a native speaker, but it means having sufficient ability to use the language to participate fully in the host society. It is easy to see how the inabil-

Material published as part of this publication, either on-line or in print, is copyrighted by the Informing Science Institute. Permission to make digital or paper copy of part or all of these works for personal or classroom use is granted without fee provided that the copies are not made or distributed for profit or commercial advantage AND that copies 1 ) bear this notice in full and 2) give the full citation on the first page. It is permissible to abstract these works so long as credit is given. To copy in all other cases or to republish or to post on a server or to redistribute to lists requires specific permission and payment of a fee. Contact Publisher@InformingScience.org to request redistribution permission. ity to communicate in the host country language could make daily life difficult and at the same time hinder social, political, and economic integration. However, this does not mean that linguistic integration and overall integration are symmetrically related to each other. In fact, mastery of the host country language does not predict integration by immigrants, and vice versa. For exam- 
ple, some French-speaking immigrants to Canada find it difficult to integrate professionally (Statistics Canada, 2007). Linguistic integration and overall integration are therefore linked in a complex relationship where other factors are at play, including social, cultural, and professional factors (Kluzer et al., 2009; Piché, 2004).

Against this background, this study looks at the current state of linguistic integration in Western societies (North America and Europe) at a time when immigration is undergoing profound changes (Pellerin, 2008) and the pervasive use of technologies since the end of the twentieth century has opened new outlooks, calling for redefinitions and a reframing of references. In addition, the potential contribution of information and communications technologies (ICT) to the linguistic integration of immigrants is explored, inspired by both the relevance of ICT for immigrants and the recent development of various online linguistic integration tools. The aim is to provide an international overview, albeit partial, of the role of ICT in the linguistic integration of immigrants at the social level, including descriptions and comparisons of ICT tools for linguistic integration. But first, and because ICT tools for linguistic integration constitute a very recent research area, we explain their relevance.

\section{The Relevance of ICT for the Linguistic Integration of Immigrants}

ICT have a major impact on migration trends by considerably diversifying and augmenting opportunities for mobility (Codagnone \& Kluzer, 2011). They also encourage people to fundamentally review their perceptions of immigrants as members of a globally interconnected community (Borkert, Cingolani \& Premazzi, 2009; Diminescu, 2005; Ros, 2010). Furthermore, like the information society (Castells, 2001) in which they live, immigrants, and more broadly speaking the immigration process, can no longer be addressed without considering the technological dimension. In this sense, mastery of ICT has become an indispensable skill for immigrants who wish to integrate into the host society and become full participants (Codagnone \&t Kluzer, 2011). In other words, technologies are everywhere in developed countries, such that successful integration demands technological integration as well as the traditionally studied social, linguistic, political, and economic integration. Inversely, lack of access to technologies, and particularly failure to appropriate them, have been proposed as exclusion factors for social integration in developed countries (Cadagnone \& Kluzer, 2011). The results in the literature are inconsistent on this point. Many studies report that immigrants and ethnic minorities have limited access to technologies and are less equipped than the host population (Benitez, 2006; Fairlie, 2005; Ono \& Zavodny, 2008). Other studies show that immigrants and ethnic minorities are better equipped technologically than the host population, notably because they use ICT to remain in contact with people back home (Cadagnone \& Kluzer, 2011; Statistics Canada, 2008). The jury is still out on this issue.

As an inherent feature of contemporary immigration, ICT can be used by immigrants for two main purposes: bonding, or using ICT to remain in contact with the home country and to maintain ethnic communities within the host society; and bridging, or using ICT to integrate into the host society (Borkert et al., 2009). These two uses are not mutually exclusive, however, as immigrants may use both (Codagnone et al., 2011).

For purposes of bridging, ICT give immigrants access to information, services, and opportunities (Kluzer, Haché \& Codagnone, 2008), including

- Official information (e.g., government websites for policies and economic and social services) and informal information (e.g., networking sites)

- Empowerment, when immigrants use ICT to make their voices heard, achieve visibility, or enter into dialogue with the host society (E.g., ethnic community sites) 
- Various services, particularly related to employment (e.g., job hunting sites) and education.

In our exploration of ICT tools for linguistic integration, we address the notion of bridging, and more specifically, ICT-supported access to services (here, educational). ICT tools for linguistic integration may be defined as technological tools designed to support immigrants in learning the language of the host society. These tools are recent, and are widespread in Western countries. For linguistic integration purposes, the tools appear to be particularly innovative for two complementary reasons:

- Pre-emigration, they allow some immigrants to pre-emptively learn the host country language before they arrive, and to pursue that learning once they get there.

- Post-immigration, they offer greater spatiotemporal flexibility than face-to-face language classrooms, so immigrants can more easily balance work and schooling.

Because they are recent, ICT tools for linguistic integration have received little attention from researchers. Therefore, the objective of this paper is to provide an initial social overview of these tools at the international level.

\section{Methods}

To gain an overview of the available ICT tools for linguistic integration, a document search was conducted, followed by a preliminary characterization.

\section{Document Search}

The document search was based on the methods proposed by Fraenkel and Wallen (2003) and Gall (2005). Accordingly, we began by formulating the research question to guide the document search, as follows: what do the ICT tools for the linguistic integration of immigrants consist of? We then determined the keywords to specifically target the linguistic integration of immigrants and entered them in various combinations into search engines, both general and scientific (e.g., Google, Google Scholar) and specialized (e.g., ERIC, Francis). As the document search progressed, we made an initial selection by skimming through the retrieved documents to ensure that they addressed the research question. Based on this set of documents, we then selected some secondary source documents, such as Kluzer et al.'s (2008) study, that appeared particularly relevant to the study, as recommended by Gall (2005). We ended by identifying 19 currently used ICT tools for linguistic integration (see Appendix). Because we did not select for technology type, a wide variety of technological tools were identified (see section on Diversity of ICT tools for the linguistic integration of immigrants).

\section{Analysis of ICT Tools for Linguistic Integration}

The ICT tools identified in the document search were subjected to a specific comparative analysis. We began with a "floating" reading (a kind of brainstorming) to allow criteria to come to light. We obtained the following list: proportion of online learning, language competencies addressed, learning support, and human interaction. We then characterized all the ICT tools according to these criteria.

\section{Results}

We now present an overview of the ICT tools for linguistic integration and provide an international comparison. 


\section{Diversity of ICT Tools for the Linguistic Integration of Immigrants}

A first notable point was the diversity of the 19 identified tools, which use technologies in various ways. At one extreme, websites such as AMEP (Australia) have the sole aim of providing information about face-to-face language classes. Designed for information purposes only, they offer no online learning as such, but simply relay information that is already available at the language centres. Other tools (e.g., Kreativpedagogik) are portals for online language resources. Not virtual education platforms, they are rather websites that direct users to learning platforms. Using ICT to further advantage, some tools (e.g., Anspear, UK; NT2 Neiuwslezer, Denmark) are applications for learning certain language expressions that immigrants would find useful. Others (e.g., FEL, Quebec; USA Learns, US) are full-fledged education platforms, with the capacity to offer actual online courses in linguistic integration. This scenario predominates among the 19 selected tools, notwithstanding the notable differences between them in terms of quality assurance. Finally, some tools (e.g., ISIS, Nova Scotia) provide linguistic integration courses under a larger socioprofessional integration program. In this case, the language courses offered on the education platform are part of a broader curriculum and, for example, may count towards professional certification for immigrants.

\section{Proportion of Online Courses}

The vast majority (74\%; Figure 1) of the tools are entirely online. However, some (16\%) complement the online content with CD-ROMs or hard-copy materials. These methods do not take full advantage of the Internet, the most interactive and evolutionary medium.

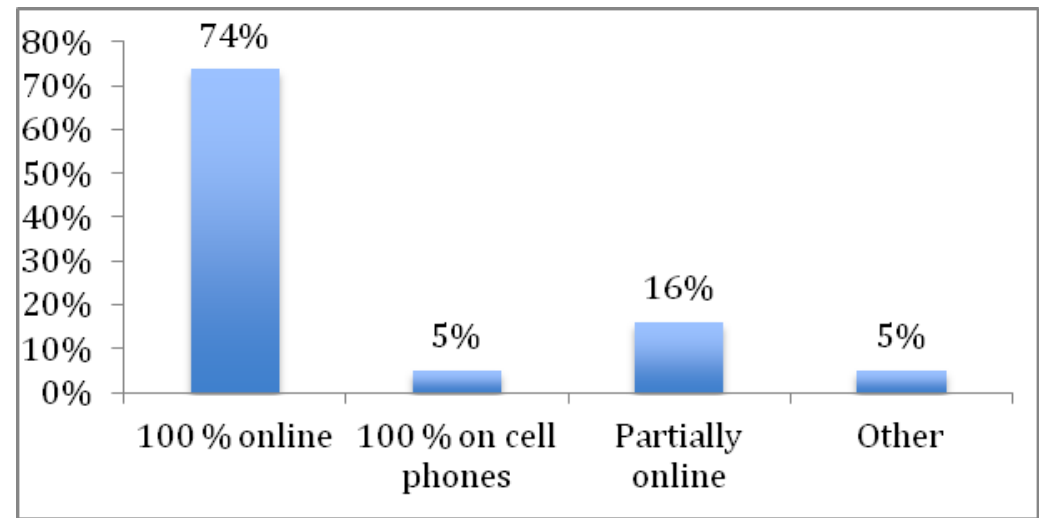

Figure 1: Proportion of online courses in ICT tools for linguistic integration.

Note that one ICT tool (accounting for 5\% of the total; Anspear, UK) offers entirely cell-phone content. This choice may appear rather restrictive for learning, as it would limit the educational potential. In fact, this tool offers mainly structural exercises such as vocabulary memorization, spelling, fill in the blanks, listening and oral comprehension, guessing word meanings from pictures, and so on. This tool therefore covers specific language aspects only. On the other hand, it appears to be highly convenient for immigrants to access and use, because the cell phone is by far the most commonly owned technological device upon their arrival in the host country (Borkert, \& al., 2009).

\section{Language Competencies Addressed}

We begin with the four basic language competencies addressed: written production (WP), oral production (OP), written comprehension (WC), and oral comprehension (OC) (Figure 2). In our 
sample, $51 \%$ of the tools addressed OC (of which $6 \%$ addressed OC exclusively, with no coverage of the three other competencies), 45\% addressed WC, $29 \%$ addressed WP, and 16\% addressed OP. These results indicate that $\mathrm{OC}$ and $\mathrm{WC}$ are given greater attention than OP and WP, and OP appears to be the least covered. This can be explained by the need for an online facilitator (a tutor, in this case), for which few of the tools have provided (see the section on Human interactions).

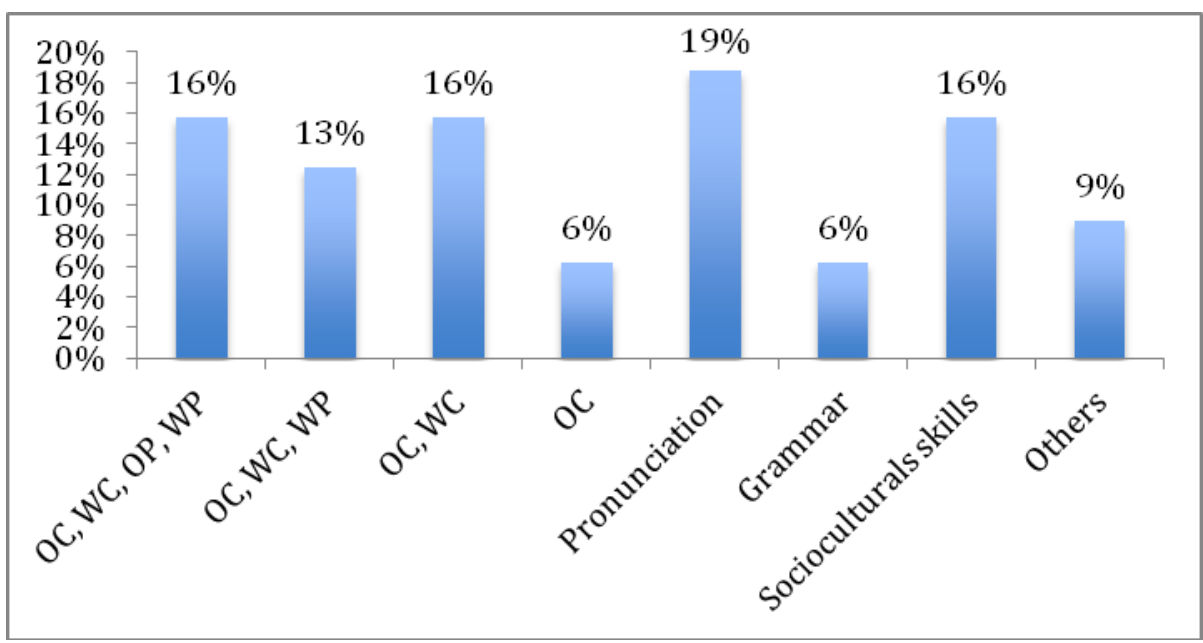

Figure 2: Language competencies addressed in the ICT tools for linguistic integration.

Among the other language competencies addressed, we found pronunciation (19\%) and sociocultural skills (16\%), which we discuss further below.

\section{Learning Support}

As shown in Figure 3, the most common types of support are exercises and other self-correct activities (35\%), followed by presentations and examples (28\%), which generally have to do with situations in the target language. Videos are also used, at 18\%. They appear to be relevant in that they add visual support to the audio message to help learners understand.

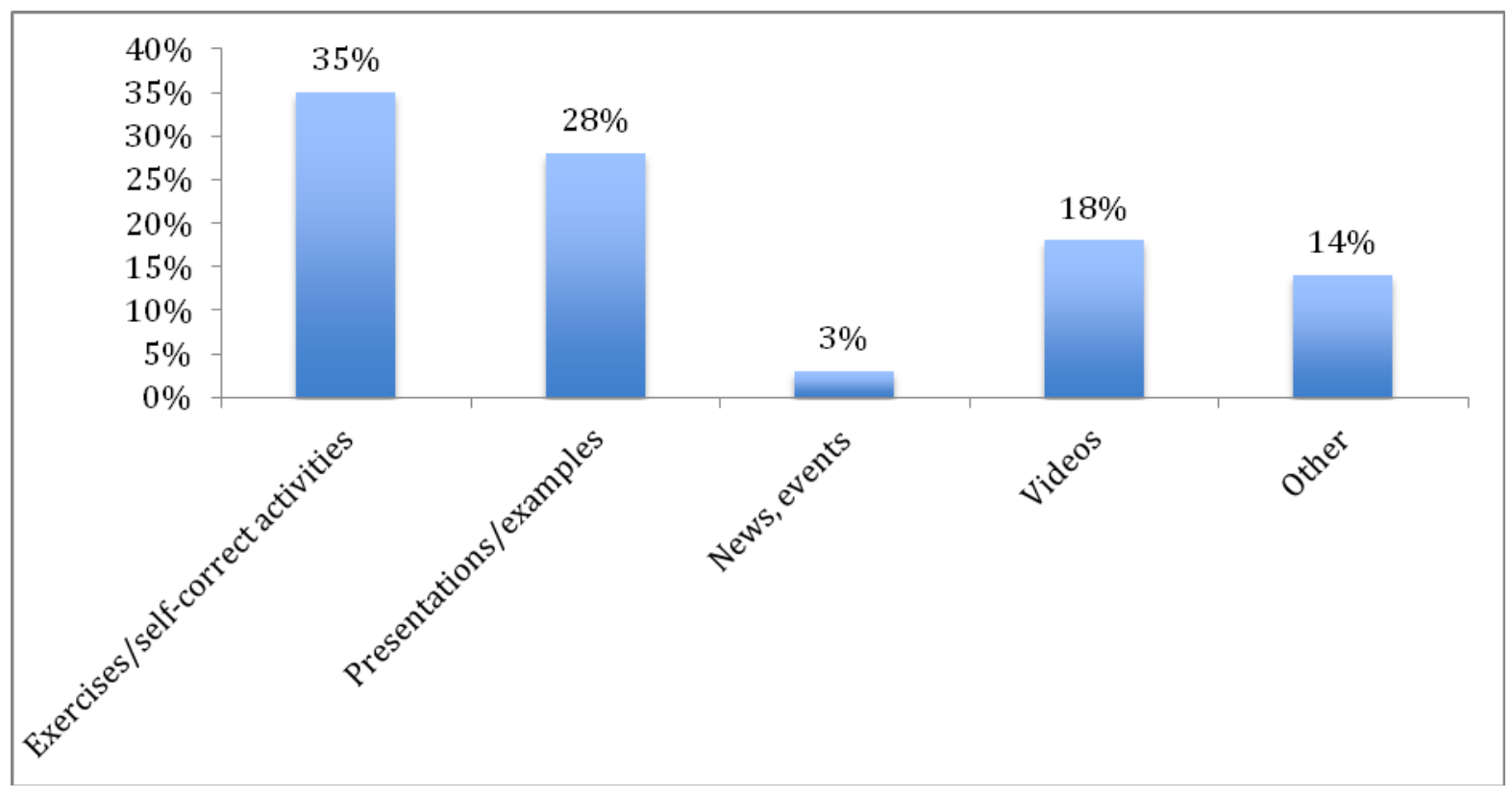

Figure 3: Learning support in ICT tools for linguistic integration. 
Note that several of the tools make maximum use of real-life rather than manufactured support materials. For example, in the Welcome Package for Migrant Workers (Scotland), various aspects of the host country such as healthcare, employment, and education are presented by professionals in the field. Thus, healthcare is presented by Dr. Dermot Gorman (Figure 4).

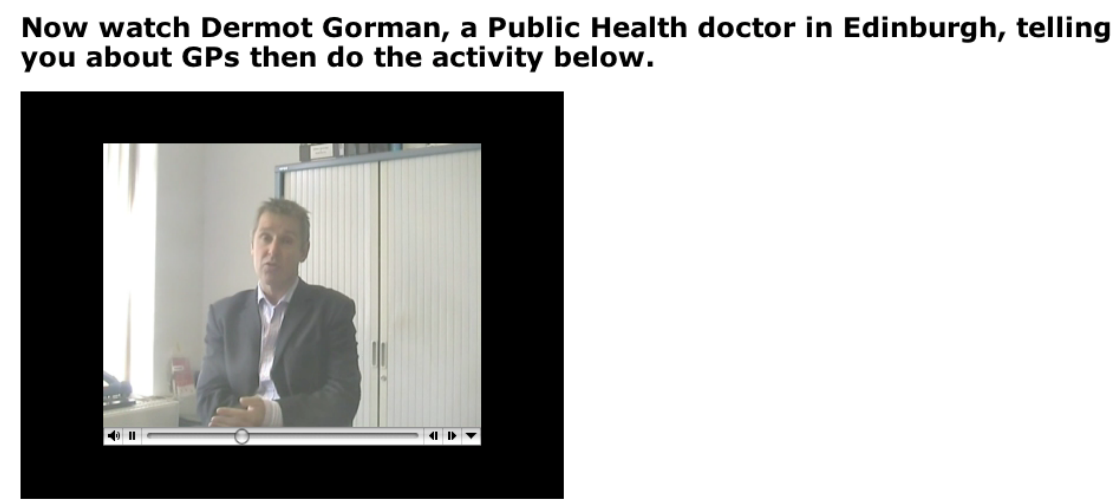

Figure 4: Real-life documentary video in the Welcome Package for Migrant Workers.

This use of real-life documentary material is relevant in that it allows learners to encounter actual situations that they are likely to experience. Given the different types of learning support used, it is noteworthy that they are all based on the principle of autonomous learning. This is consistent with the fact that few of them offer human support, as we shall explore next.

\section{Human Interaction}

As seen in Figure 5, most of the tools (65\%) provide no human interaction. This finding concurs with previous results showing that $\mathrm{OP}$ is a neglected competency, due to the need for human support (see the section on Language competencies addressed). This also explains why the learning support provided (see the section on Learning Support) is designed for autonomous learning. This suggests that because most ICT tools do not generally provide for human interaction, they would be unlikely to cover all the language aspects needed for adequate integration. In fact, the absence of human interaction favours the development of certain competencies and discourages the development of others, in particular OP. Yet OP is an essential asset for immigrants when they arrive in the host country. ICT tools that fail to address this competency would therefore support only some aspects of linguistic integration, and not overall integration.

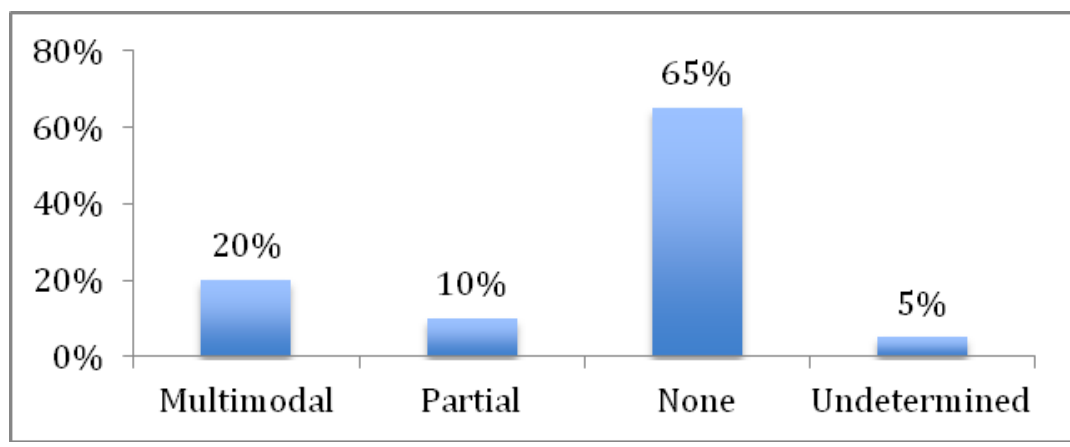

Figure 5: Human interaction in ICT tools for linguistic integration. 
On the other hand, some (20\%) ICT tools offer multimodal human interaction, including online tutors to help learners develop oral competencies. This type of ICT tool is designed to support overall language development by immigrants. For instance, Français en ligne (French online) was developed by Quebec's ministry for immigration and cultural communities (MICC). Finally, some tools (10\%) offer partial human assistance on request. However, within the scope of this study, it was impossible to determine how effective this human assistance is.

\section{Conclusion}

The objective of this paper was to provide an overview of ICT tools for the linguistic integration of immigrants. Not an exhaustive examination, it presents a general idea of the broad trends. We found considerable variation in the identified ICT tools, most of which are designed for autonomous learning with no human interaction (for instance, no tutors). This in turn implies limited learning situations, particularly for oral production.

Based on this rough social and scientific portrait of ICT tools for the linguistic integration of immigrants, we may propose some avenues for future research. First, in terms of methods, a deeper analysis of immigration factors (e.g., age, sex, ethnicity, education level, integration stage) in relation to the linguistic integration tools could be undertaken. Second, immigrants' uses of these tools and their behaviours surrounding them could be explored. The idea would be to use a more comprehensive approach to gain a deeper understanding of the obstacles, motivations, and perceptions of immigrants concerning the use of these tools. An impacts analysis would be another instructive direction to consider, in relation to the use and behaviour analysis. Ultimately, the issue would be to determine the impact of ICT tools for linguistic integration on the social, political, and economic integration of immigrants into the host country, along with the appropriate conditions for their use. They could also be studied in combination with non-technological methods such as face-to-face classroom sessions. Nevertheless, these research avenues would not provide information on immigrants' access to or use of ICT, which are cross-cutting conditions for the effectiveness of any ICT tool for linguistic integration.

\section{References}

Beacco, J-C. (2008). Politiques d'intégration des migrants adultes : Principes et mise en œuvre. Division des politiques linguistiques, Conseil de l'Europe.

Benitez, J-L. (2006). Transnational dimensions of the digital divide among Salvadoran immigrants in the Washington DC metropolitan area. Global Networks, 6(2), 181-199.

Borkert, M., Cingolani, P., \& Premazzi, V. (2009). The state of the art of research in the EU on the take up and use of ICT by immigrants and ethnic minorities. Luxembourg: Office for Official Publications of the European Communities.

Castells, M. (2001). La société en réseaux. Paris : Fayard.

Codagnone, C., \& Kluzer, S. (2011). ICT for the social and economic integration of migrants into europe. Luxembourg: Office for Official Publications of the European Communities.

Diminescu, D. (2005). Le migrant connecté. Pour un manifeste épistémologique. Migrations/Société, 17(102), 275-292.

Fairlie, R. (2005). Are we really a nation online? Ethnic and racial disparities in access to technology and their consequences. Report for the Leadership Conference on Civil Rights Education Fund. Retrieved 2012, March, from http://www.civilrights.org/publications/nation-online/digitaldivide.pdf

Fraenkel, J. R., \& Wallen, N. E. (2003). How to design and evaluate research in education (5th ed.). Toronto: McGraw-Hill.

Gall, J. (2005). Applying educational research: A practical guide. New-York: Pearson. 
Kluzer, S., Ferrari, A., \& Centeno, C. (2009). ICT for learning the host country's language by adult migrants in the EU. Luxembourg: Office for Official Publications of the European Communities.

Kluzer, S., Haché, A., \& Codagnone, C. (2008). Overview of digital support initiatives for/by immigrants and ethnic minorities in the EU27. Luxembourg: Office for Official Publications of the European Communities.

Lapierre Vincent, N. (2004). L’intégration linguistique au Québec : recension des écrits. Québec : Conseil supérieur de la langue française.

Nedelcu, M. (2009). Du brain drain à l'e-diaspora: Vers une nouvelle culture du lien à l'ère du numérique. TIC et société, 3(1-2), 152-173.

Ono, H., \& Zavodny, M. (2008). Immigrants' English ability and the digital divide. Social Forces, 86(4), 1455-1480.

Pellerin, H. (2008). Les politiques migratoires : Vers un changement de paradigme. Centre Métropolis du Québec, 34, 1-16.

Piché, V. (2004). Immigration et intégration dans les pays développés : Un cadre conceptuel. In G. Caselli, J. Vallin \& G. Wunsch (Eds), Démographie : Analyse et synthèse. VI : Population et société (pp. 159178). Pari, Éditions de l'Institut national d'études démographiques.

Ros, A. (2010). Interconnected immigrants in the information society. In A. Alonso, \& P. Oiarzabal (Eds.). Diasporas in the new media age: Identity, politics, and community (pp. 19-39). Reno: University of Nevada Press.

Statistics Canada. (2007). Le portrait linguistique en évolution, Recensement de 2006. Ottawa, Minister of Industry, Canada.

Statistics Canada. (2008). Canadian Internet Use Survey. Ottawa: Statistics Canada.

Appendix

\begin{tabular}{lll}
\hline $\begin{array}{l}\text { Country / } \\
\text { province }\end{array}$ & Name of tool & URL link \\
\hline
\end{tabular}

\begin{tabular}{|c|c|c|}
\hline Australia & $\begin{array}{l}\text { Adult Migrant English Pro- } \\
\text { gram (AMEP) }\end{array}$ & $\begin{array}{l}\text { http://www.immi.gov.au/living-in-australia/help-with- } \\
\text { english/amep/ }\end{array}$ \\
\hline Denmark & Dansk.nu & Www.dansk.nu \\
\hline Denmark & Dansk her og nu & http://www.danskherognu.dk/ \\
\hline Denmark & NetDansk & http://netdansk.asb.dk/Default.htm \\
\hline Denmark & Danmark til daglig & $\begin{array}{l}\text { http://www.nyidanmark.dk/bibliotek/multimedier/intera } \\
\text { ktive_ressourcer/2007/danmark_til_daglig/index.html }\end{array}$ \\
\hline Denmark & Ultimate Danish & http://ultimatedanish.dk/index.php \\
\hline Denmark & Speak Danish & http://www.speakdanish.dk/ \\
\hline Denmark, & $\begin{array}{l}\text { Welcome Package for Mi- } \\
\text { grant Workers }\end{array}$ & $\begin{array}{l}\text { http://www.workmobility.eu/default.html + livrets de } \\
\text { phrases traduites en plusieurs langues (www.mobidik.dk }\end{array}$ \\
\hline $\begin{array}{l}\text { Scotland, } \\
\text { Lithuania, } \\
\text { Norway, }\end{array}$ & & ou www.travellingua.eu) \\
\hline Poland & & \\
\hline
\end{tabular}




\begin{tabular}{|c|c|c|}
\hline Germany & Yabla German & $\begin{array}{l}\text { http://german.yabla.com/?gclid=CKjNlqfPpqoCFVDCK } \\
\text { godwnfQVg }\end{array}$ \\
\hline Netherlands & Thuis in Nederlands & http://www.thuisinnederlands.nl/methodiek/virtuelewijk/ \\
\hline Netherlands & NT2 - Nieuwslezer & http://www.nt2nieuwslezer.nl/ \\
\hline Norway & Migranorsk & $\begin{array}{l}\text { http://www.migranorsk.no/index.php?show=73\&expand } \\
=93,73\end{array}$ \\
\hline $\begin{array}{l}\text { Nova Scotia } \\
\text { (Canada) }\end{array}$ & $\begin{array}{l}\text { Immigrant settlement and } \\
\text { Integration Services (ISIS) } \\
\text { online learning community }\end{array}$ & http://onlinelearning-isisns.ca/ \\
\hline $\begin{array}{l}\text { Quebec } \\
\text { (Canada) }\end{array}$ & Francisation en ligne (FEL) & $\begin{array}{l}\text { https://www.francisationenligne.gouv.qc.ca/ et } \\
\text { http://www.immigration-quebec.gouv.qc.ca/fr/langue- } \\
\text { francaise/apprendre-ligne/index.html }\end{array}$ \\
\hline Spain & Aula Virtual de Espanol & http://ave.cervantes.es/ \\
\hline Sweden & Kreativ Pedagogik & http://www.kreativpedagogik.se/ \\
\hline Sweden & Lingua 2 : Swedish & $\begin{array}{l}\text { http://www.si.se/English/Navigation/Learning- } \\
\text { Swedish/Web-course-in-Swedish/ }\end{array}$ \\
\hline $\begin{array}{l}\text { United King- } \\
\text { dom }\end{array}$ & Anspear mobile learning & www.anspear.com/learning \\
\hline United States & U.S.A. Learns & $\begin{array}{l}\text { http://www.usalearns.org/index/welcome.cfm?CFID=25 } \\
\text { 77196\&CFTOKEN=60941635\&jsessionid=3c309494e33 } \\
\text { 7017ff198169791925173c3359 }\end{array}$ \\
\hline
\end{tabular}

\section{Biography}

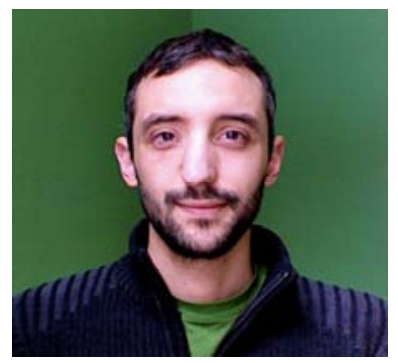

Simon Collin, M.Sc., Ph.D., is a professor in the Faculty of education of the University of Quebec in Montreal. He is also a research member of the Centre de recherche interuniversitaire sur la formation et la profession enseignante (CRIFPE). His academic training and his research interests center upon second language teaching and learning, Information and Communication Technologies (ICT) and immigration and ethnic minorities. He has already taken part in many national or international research projects and has published several academic and pedagogical works.

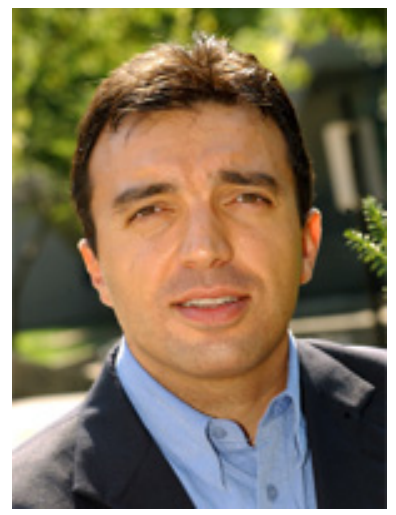

Thierry Karsenti, M.A., M.Ed., Ph.D., holds the Canada Research Chair on information and communication technologies (ICTs) in education. He is also a professor at the University of Montreal, in the field of information and communication technologies and their integration in teacher training and education. His technopedagogical achievements and innovations have been recognized at both the provincial and national levels. He has also been recognized for his contributions, through research activities, to the quality of pedagogy. His research interests center upon the pedagogical integration of new technologies, teaching practices and motivation. 